\title{
Heritage Legal, between Albania and Italy
}

\author{
Phd. Adrian Leka \\ Faculty of Law, University "Luigj Gurakuqi" \\ Email: leka-ad@live.com
}

\section{Doi:10.5901/mjss.2016.v7n6p397}

\begin{abstract}
Right great heritage, a branch of civil law is very old branch which has been implemented since early Roman times, but evolved from that time until positive today. Our rights as the basis for the call in heritage and provides legal inheritance by law testamentary. Our priority civil is the testament. Civil Code of the Republic of Albania to the contract excludes heritage which foresee almost all European legislation. By addressing the issue of legal heritage in Albania my study focuses on a comparative analysis of legal regulations in the field of heritage with Italian law provided for in the legislation. Purpose of this comparative analysis is the identification of common and main differences between Albanian and father Italian legislation in the field of heritage main legal. The major issues are: Principles the general regulation, the basics of calling the inherited systems of transfer of the hereditary estate, Ability to inherit the role and position and spouse / the survivors, children legitimate, natural and to adopt the deceased, the share of legal heirs depending on their order in the call that we inherited. Inheritance law which applies numerous practice of our country, as set out in this law, acting in the absence of a will, when the will is declared partially or completely invalid accessed trailer or when by the will is disposed only a portion of the hereditary estate. Everyone admits that legal action has been and testament is a legal act or act a little known and used in the our country. Reasons relating to economic and social relations, which in Albania are not shown as contours in typical minimums formations feudalcapitalist.Stagnant intermediate forms, that have significantly impacted the property relations affected the property scheme for the Heritage Institute. According to court statistics, the majority of persons we die without leaving a will, then, hereby conclude that inheritance laws it takes a special importance not only legal but also practical.
\end{abstract}

\section{Civil Code of 1929}

Albanian legal system composed of multiple layers and each of them belongs to a particular historical period. Albania's history is characterized by the inversion of violent toward each stratification, originating from a culture and a completely different ideology. For this reason, these layers are distinct from each other, and this is evident even at a superficial glance, especially if we refer to the heritage institute. By Civil Code of 1929 which was the first legislation was arranged so versatile civil legal relations in Albania, until the civil code of 1994, which finds application and currently, we can identify some of the main differences that characterized the Albanian legislation relations in general and heritage in different stages of time. These differences can we see in some aspects as:

- $\quad$ Rare call we inherited the legal heirs and their belonging parts.

- The role of the surviving spouse, who if he is the sole heir of the rarity of rarity first or second; It competes and down a ladder below the heirs of the rarity third.

- The role of the child that heritages, change the position of adopted children or those with natural compared to heritages legitimate children.

Zog Civil Code, which was adopted in 1928, entered into force on 1 April 1929 contain provisions on legal and testamentary inheritance in his second book, which was divided into three titles (articles 454-773). This code, Article 33 of the Law "On the application of the Civil Code", established that: "Heritage is a person who has death before enter into force of the new code, according wither previous laws." According to this code bases we call heritage are two: the law and testament. Article 454 of the 1929 K.C admitted that "Heritage comes by law or by will." We also get involved with the Civil Code that the inheritance law has place only:

- When Lack of respect testamentary inheritance, and;

- The share of wealth that can't receive it with a will (legal reserve). 


\subsection{Decree "On inheritance" 1954 (1956)}

Positive legislative tradition established around the 30 th, although in a country where economic relations existed in the original format, suffered significant changes during 1945-1990, period corresponding to the liberation of the Nazi-fascist invaders associated with the change of political system have assigned. Property relations, as a result of socialization of the means and material goods in general (Marxist philosophy), significantly shrinking individual-property report established for centuries, which caused the individual to lose interest in the fate of his property. Need to emphasize a legislative fact that belongs years 1946-1954, a period in which the inheritance rights, due to the abolition of all national whole preceding laws, for those acts that do not conflict with the social order of the time, regulated by the 1929 civil code while for some institutes of the guidelines of the plenum of the Supreme Court. Decree number 1892 dated 05.07.1954 " On heritage ", under the influence of the communist regime of that time, authorize a new order of relations heritage. In this act was arranged in full of all the issues that related to the legacy, ranging from understanding and time of opening of the inheritance, their ability to inherit, the circle of legal heirs and of them will form the will of others to the division on inheritance. Capacity to inherit by decree in 1954 had " only the person at the time of opening the inheritance is alive or has been conceived and born alive after the death of the deceased.

\subsection{The 1981 Civil Code}

Civil Code that was approved by 06.26.1981 entered into force on 1 January 1982 in the spirit of the Constitution of 1976, brought a regression in the regulation of civil legal relations, between the elimination of private property and sanctioning the 'Property state 'of all. Sanctions of this legal regime also reflected in particular at the moment of opening the inheritance, it was accompanied by a limitation of the heritage institute, treating it as a form of gaining ownership. In the transitional provisions of this Code and namely Article 352 stipulates " provisions of gaining ownership through inheritance shall apply to the territories that are hatched before the entry into force of this code, when the inheritance is no agreement to co-heirs with a court or by notery act '. In Article 94 of the Civil Code of inheritance given meaning: " legacy is passing by law or by will of property of the deceased person (deceased) a person or more persons ". Also accept that inheritance law was room when:

- The heir has not made a will.

- The will is completely or partially invalid

- When we dispose testament it is only part of the property.

The 1982 civil code limiting sequence call the legal heirs to the gender of the third degree.

We rarely see, we called legacy children, spouse and parents unable to work.

We rarely second called spouse able to work, he was the only heir of the rarity first, parents are able to work, and people unable to work which at least one year before the death of the deceased, cohabited with as member family and were charged to him.

We rarely third called person is unable to work when not compete with other heirs of the second thinning, grandparents, brothers and sisters, and brothers and sisters, children of the deceased before. We rarely the fourth, there was no legal heirs in any sparse or they were indecent or withdraw or were kicked out, then as heir called the state (Article 107).

\section{Civil Code of 1994}

The Civil Code of 1994 es heritage relations are regulated in Part III, Sections 316-418. Their regulation in fact, is done taking into account the norms of the decree " inheritance " of 1954, and maintaining the norm of any civil code of 1929. Civil code in i'ts transitional provisions has sanctioned the rule that: " The Civil Code of the Republic of Albania apply to legal relationships created after its entry into effective "let to assume that this code will not have a retroactive effect for regulation relations heritage for them, according to the definition given by Article 318 of the civil code, shall be governed by the law of the time when the testator dies.

Laws regulating inheritance relationships are included in the third part of the Civil Code, as the basis for regulation of the civil code serving their Constitutional norms. Heritage as a way of gaining ownership is recognized by Article 165 K.C, but in full, the problems related to being arranged in the third part. 


\subsection{Terminology}

The biggest differences of terminology to the inheritance law exist between continental European system of law and England-American system of law. Here we will take in consideration only those terms that are used most often, which are:

With inheritance rights as institute of civil law, the right branch of unique Republic Albania -that means the entirety of legal norms issued by the state which, regulate property relations arising due and after that a person and that over governing the inheritance from the decedent to his heirs.

Testator is called the person whose property after his death, exceeds one or several persons under the law when it made a will, or a person or persons designated in the will.

Testator are people who have legal capacity regardless of whether or not the capacity to act.

Heirs are persons to whom, pursuant to law or by will, passes the dead person's property after his death. May be heirs: persons, legal entities and state.

Understand the totality of inherited property rights that go from the decedent to his heirs after death.

Hereditary wealth means not only items but the entirety of the rights and obligations of the deceased, which I pass on to his heirs. Wealth that can be inherited are any property, movable and immovable property, as well as items that are exempted from civil circulation.

\subsection{Principles of inheritance.}

Civil Code regulating relations heritage is governed by the following criteria:

- First, while the law recognizes and protects citizens' property ownership passes to heirs under the law will.

- Second, the circle of persons who may be called to inherit defined by law and includes his closest people.

- Third, we call legacy be based on the degree of proximity survivors and deceased.

- Fourth, accepted equality between men and women, between men and women, between children born in wedlock and those born out of wedlock.

- $\quad$ Fifth, accepted the equality of parts among survivors was called in heritage.

- Fifth, civil code recognizes freedom of testamentary disposition of property, but protects the inheritance rights of minor children and persons unable to work.

\section{Handling of legal heritage in Italian legislation. Italian Civil Code}

Regulatory basis in reality heritage is Italian Civil Code. The Italian law regulating the institute in heritage based on these principles:

- Legacy opens in the moment of death, the last place of residence of the deceased.

- The inheritance passed on or under the law or by will.

- Arrangements for future heritage are prohibited, acceptance gained effective heritage, which starts from the day of opening the inheritance.

- Are able to inherit those who have been or are conceived at the time of opening inheritance.

- The principle of equality between co-heirs. By this principle, and the extent of equality of natural children and spouse, inheritance today's legal is disconnected from any notion that may exist regarding the hereditary estate as an asset belonging to the family and that was destined to stay within it.

Inheritance passes by law or by will, which can be: the legacy of legal inheritors acting in the absence of a will and inheritance necessary (heredes necessari) that operates in the presence of a will or other acts without compensation that damaged the rights that the law recognizes legal inheritors.

\subsection{The general principles of legal regulation in the legislation Italian heritage.}

Some of the general principles of legal regulation of inheritance are:

- Unworthiness.

- Representation.

- Acceptance of inheritance.

- Petition of inheritance. 
- Replacement.

- The ability to dispose of and take.

- Ability to inherit.

Finally: The 1975 law also made a change in the position of natural children, who were subject to discrimination. Heirs are obliged in proportion to what they have taken to discharge children natural as well as those born from an incest absolute, a retired subsistence equal to the amount of income the part that will be meet if sonship would be declared or known, or if the father or mother have not available in their favor with donations or testament.

\section{The general principles of legal regulation of inheritance in international law.}

Overall historically movable heritage items regulated under the personal law of the deceased estate while for those citus lex. Such principles calls so far as, on the basis of their right to create a kind of uniform joint with many countries. Unitary system of legal regulation of inheritance and an advantage of nationality was dominant in regulating the right of heritage in Europe during the 19th century.

From the standpoint of private international law currently there are two major groups of legislation concerning the regulation of relations arising from legacy: on one side are legislations an underlying unity of regulation heritage, namely the appointment of a single law to regulate relations heritage in all its aspects, and on the other are legislations from such an arrangement exclude immovable properties being put up as a rule that for these, and for the effects of inheritance, to apply the law of the place of their occurrence reaching fractioning heritage in a special heritage as we are and applicable legislation due to the location of the immovable object.

\subsection{Legal regulations in the Albanian international law.}

The first legal provisions regarding the regulation of heritage in private international law and our country after the Second World Lutes are rates 39201964 law, namely Articles 14 and 15 of this law. Under Article 14 of the law in question 'relationships arising from inheritance are governed by the legislation of the State of which the decedent was at the time of death, regardless of the type of hereditary estate or the place of its occurrence. In fact Article 14 of Law 3920 of 1964 has generally been accepted that principle but that unity breaks down when the inheritance of a foreigner are part of real estate located in Albania.

\section{Conclusions}

1. The differences between two French and Italian legislation on the regulation of inheritance law:

- The acceptance of the legacy system.

- Cases of unworthiness.

- Ability to inherit.

- The share of legal heirs.

- The position of adopted children and natural to them.

- The position of the surviving spouse and the deceased share.

- Heirs by two legislations.

2. Shared between French and Italian legislation on the regulation of inheritance law.

3. Fundamentals of call we inherited.

Rare's legal heirs.

- The general principles of the law regulating inheritance.

- Provides a legal reserve.

In sum, the right of inheritance law in Albania is provided in the form of regulated and fully in the 1929 Civil Code, the decree " Heritage " the 1954 amendments of 1961 and 1973 in the civil code 1982, in the 1994 civil code was accepted unanimously by the lawyer in the field of civil code of 1929 is notable in terms of quality of the content associated with the heritage Institute, as not only is contemporary concepts being formulated according to the European law of the time, mainly Italian, French, etc., but more adjustment provisions noted with customary rules, which constituted a social order for the new state of Albania in the field of law.

As for the civil code of 1994 , he said that the right to inheritance significantly improved compared with the civil code of 1982, but that the judge failed to break away from the east of the right system. Even the few provisions that were 
adopted by the civil code of 1929 did not bring further substantial changes after receiving function meeting the norms, although civil code of 1994 aimed to precede entirely as economic-social relationship of being restored. This conclusion is based, inter alia, by analyzing rates constituent institute of the inheritance law, in particular on legal inheritance norms in legislation. Summing up the legal analysis of the right of inheritance in the civil code of 1994, judge that he failed to qualitatively improve relations hereditary in particular that law. This conclusion is not based only on the fact why he was removed Pattern east, but also in that the interference with the norms it did not bring any innovation this has been noticed by a large proportion of lawyers who have expressed insufficiency and uncertainties content this institute.

While analyzing the interpretation beyond the norm, not rule out that to give the image of 'goods in the country' 'by law Certain adaptations have been intended Maker individualism of our legislation sispas tradition characteristics of Albanian society.

\section{References}

Arben A Haqani, Inheritance, legislation and judicial practice, Dudaj Publishing, 2010, page 38.

Arben A Haqani, bep quoted, page 38.

Dr. Juliana Latifi, quoted act, page 6.

Hamdi Podvorica, Inheritance Law, University " Dardania ", Pristina, 2006.

Hamdi Podvorica, criminal quoted, page 19.

Nazmi Bicoku, " The inheritance Rights of the Republic of Albania ', Onufri Tirana 1999, page 35-36.

Dr. Juliana Latifi, civil edrejta " Heritage ", GEER, 2007, page 23-29.

Juliana Fuga (Latifi), Inheritance, Tirana 1999, page 49.

Francesco Galgano, Private Right, LUARASI, Tirana, 2003, page 992.

Ardian Kalia, Private International law, page 181.

Eduardo Vitta, "Diritto Internazionale Privato", vol III, "Legal and Testamentary Inheritance".

Av. Dawn of Tartarus, a criminal quoted, page 16-39.

H.Batiffol and P.Lagarde, "Traite 'de droit International Prive", v.2, Paris, 1971 page 301.

N. Bicoku, the inheritance rights of RPSSH, Tirana, 1984, page 41.

New Developments in Succession Law: The U.S Report, vol. 142 Electronic Journal of Comparative Law, (October 2010). http://www.ejcl.org/142/art142-5.pdf

Civil Code of the Republic of Albania, September 2003.

Family Code of the Republic of Albania.

The Civil Procedure Code of the Republic of Albania.

Code of the Socialist People's Republic of Albania, Tirana 1982.

Italian Civil Code. 